Meta

Journal des traducteurs

Translators' Journal

\title{
German ad hoc Compounds in Translation
}

\section{Catherine Mealing}

Volume 35, numéro 1, mars 1990

Actes du colloque international « La traduction proligère "

URI : https://id.erudit.org/iderudit/003610ar

DOI : https://doi.org/10.7202/003610ar

Aller au sommaire du numéro

Éditeur(s)

Les Presses de l'Université de Montréal

ISSN

0026-0452 (imprimé)

1492-1421 (numérique)

Découvrir la revue

Citer cet article

Mealing, C. (1990). German ad hoc Compounds in Translation. Meta, 35(1),

177-187. https://doi.org/10.7202/003610ar d'utilisation que vous pouvez consulter en ligne.

https://apropos.erudit.org/fr/usagers/politique-dutilisation/ 


\section{GERMAN AD HOC COMPOUNDS IN TRANSLATION}

Catherine Mealing

Concordia University, Montréal, Canada

This paper considers noun compounds in present-day German and their translation into English and French, whereby special emphasis is placed on the so-called ad hoc formations ( $c f$. below). The purpose of this is twofold: first, to isolate a set of lexical forms observed in a corpus of texts and thereby to identify a specific and generalizable translation problem ( $c f$. Neubert (1981: 27)); and second to propose, on the basis of a text linguistic analysis of these forms, a means of adequately rendering them in the two target languages. The goal, therefore, is not merely to isolate a problem which to my knowledge has not previously been identified in translation theory, but also to suggest a solution.

The importance of text linguistics to translation theory is now generally recognized, and is central to the question of adequacy, or equivalence, in translation. As has frequently been observed (for instance in Dressler (1987), Wilss (1981), Neubert (1981), Coseriu (1978) among others), adequacy is achieved at the level of text, since it is precisely at this level that language functions communicatively. Consequently, communicative equivalence represents a basic requirement of any translation. This emphasis on communicative equivalence is justified inasmuch as any linguistic sign occurring in a text functions in that text, i.e. it cannot meaningfully be considered in isolation from the context which gave rise to its use, except in a virtual sense ${ }^{1}$. Furthermore, the text, which is an organized series of such signs, itself occurs in some communicative situation, from which it cannot be divorced. Translators are therefore always concerned with language use in a given linguistic and extralinguistic context.

In recent years, pragmatic definitions of equivalence have become prevalent. However, as Komissarov (1987) stresses, the importance of pragmatics to translation has sometimes been emphasized to the detriment of semantics. While no one would deny that pragmatic considerations such as the situation of utterance, the intended effect of the text, its intended audience, the cognitive knowledge of both producer and recipient(s), etc., are of considerable importance for equivalence, Komissarov (418) reminds us that communication is effected through the text, that is, a set of properly organized language units and that the interworking of the meanings of these units results in the formation of text semantics of relative stability. He points out further (419) that the information in the text is potentially accessible to anyone with a mastery of the given language, which is therefore a function of linguistic meaning, and not of the recipient's cognitive knowledge. From this one can only conclude that texts (and thereby communication) ultimately depend on a complex interaction of both semantic and pragmatic factors. Consequently, translation equivalence in turn must depend on interaction in the target language text of these two levels; any translation which fails to render both must be rejected as inadequate.

Assuming the text as the basic linguistic unit, one can only concur with Coseriu (1978: 31) that the central question in translation is the expression in different languages of the same text content. In this connection, he distinguishes (32) three types of linguistic content (i.e. sprachlicher Inhalt), namely Bedeutung (meaning), Bezeichnung (designation) and Sinn (sense). Bedeutung he defines as the content of an individual sign, which 
therefore is language-specific. Bezeichnung has to do with reference to an extralinguistic entity, which however can be achieved only by means of the linguistic sign, i.e. Bedeutung. By Sinn he understands the content of a text or text passage, insofar as this can be distinguished from Bezeichnung. This therefore concerns both pragmatics and the semantic relations established in the text between the referring signs. ( $C f$. Komissarov's interworking of meanings.) The task of the translator then is to render in the target text, by means of target language Bedeutungen, the same Bezeichnung and Sinn as are expressed in the source text. Translation is thereby both a semasiological and an onomasiological process, in which the translator first analyzes the source language text on a semanticpragmatic basis, and then proceeds to reencode this meaning (understood as the composite of Bezeichnung and Sinn) in the signs of the target language. Coseriu states emphatically (33-34) that Bedeutungen are not translated.

This bears directly on the question of the ad hoc formations, which, as linguistic signs, necessarily represent Bedeutungen. Consistent with Coseriu (1978), it is claimed here that adequate translation of these compounds is possible only within the framework of the texts in which they occur.

These ad hoc compounds are formed in relation to a particular text, and can be readily distinguished from lexicalized compounds, which by contrast are established as part of the common vocabulary of a speech community, and which would, for example, be entered in a dictionary. Examples from German are Wollteppich (wool carpet/tapestry) - a lexicalized form - and Romanteppich (novel carpet/tapestry) — an ad hoc form, where novel refers to the literary text sort ${ }^{2}$.

It is claimed here that because of the text dependence of the ad hoc forms, which for all practical purposes renders them unintelligible when cited out of context, these compounds can be adequately analyzed only from the point of view of text linguistics. It is further argued that ad hoc forms fulfill a cohesive function in texts, and that their adequate translation is therefore dependent on analysis of just this cohesive role.

The problem is first considered here from the point of view of linguistic theory, and subsequently its application to translation is discussed. As is well known, all compounds in a given language are formed on the basis of the rules of word formation of that language. Consequently, the two types of compound are structurally indistinguishable in that both conform to the same set of formal criteria and are therefore constructed in accordance with the same models. A speaker of German therefore is able to discern for instance that for both Wollteppich and Romanteppich the first component modifies the second, that both compounds consist of two noun stems and that compounding two such stems results in another noun. These are the formal criteria concerning the morphological structure and the morphologic shape of compounds, as identified for instance in Marchand (1967: 379-380).

This structural knowledge, however, is not sufficient for interpretation of compounds, as the way in which the first component modifies the second is not explicit in the forms themselves. For this reason, Polenz (1985: 26-27) refers to compounding as a compressed means of expression, by which he means that any paraphrase of a compound necessarily contains more forms than are contained in the compound itself. In the case of Wollteppich, then, the speaker interprets the compound on the basis of his additional knowledge of its lexicalized meaning, whereas the meaning of the ad hoc form Romanteppich must be deduced from the text in which it is used. That is to say, the semantic relation between the components of Wollteppich is disambiguated by the lexicalization of the compound, whereas the relation between the components of Romanteppich is disambiguated solely by the text. 
On the basis of these observations, the two types of compound can be considered in relation to Coseriu's (1975) hierarchical levels of system, norm and speech. As I interpret this hierarchy, the system dictates the model in accordance with which words are formed, while the formal structures inherent in the system are necessarily found in the formations themselves (i.e. the compounds provide the empirical data from which the system can be abstracted). The use of a given form in a particular text, however, pertains to the level of speech. The fact that the form exists as part of the established vocabulary of the language makes that form a part of the linguistic norm.

Speakers can, of course, coin new words which conform to the system, and which are used in texts, but which are not part of the linguistic norm. This is precisely the case of the ad hoc compounds. Both lexicalized and ad hoc forms are appropriately analyzed with respect to system and speech (because both are constructed in relation to the same models, and because both function in texts), whereas they differ in their status with respect to the norm. For the ad hoc compounds, because of their dependence on text for both their formation and their interpretation, no norm meanings can be posited. Consequently, syntagmatic description of them is restricted to system and speech.

Paradigmatically, however, ad hoc compounds can also be considered in relation to lexicalized forms in the norm containing one common element. Wollteppich could for instance be associated with Wollmantel (wool coat), Wollhut (woolen hat) and Wolldecke (woolen blanket). Similarly Romanteppich can be related to Romanautor (novelist), Romanfigur (character in a novel) and Romantitel (title of a novel). Other compounds with the second component -teppich include for example Seidenteppich (silk carpet) and Wandteppich (wall carpet $=$ tapestry).

Ad hoc compounds function cohesively in texts, and in fact instantiate two particular processes of text constitution, namely recurrence and isotopy. Recurrence has to do with reiteration of terms in a text, such that lexical items occurring at one point in it are taken up again at a subsequent point. This is therefore an anaphoric means of connecting the various sentences of a text to each other. It concerns morpho-syntactic manifestations of underlying semantic relations, and has to do in particular with textual co-reference. When reference is made to the recurrence of forms therefore it is always with the understanding that in fact this surface cohesion concerns the semantic level, i.e. coherence ${ }^{3}$. As a process, recurrence is not restricted to simple repetition of forms, but can also involve word formation processes as noted for example by Schröder $(1978 ; 1985)$ and Dressler (1981d). Schröder (1978: 85) observes that the common stem (i.e. a word stem recurring across a text or text passage - C.M.) names a superordinate point for a group of denotata, and it signals lexically membership in this group. Accordingly, she identifies word formation processes involving the same stem as a means of text constitution, whereby the surface recurrence of some stem can serve to establish semantic relations across a text.

Isotopy also concerns semantic relations within texts, and has to do in particular with the recurrence of semantic features common to groups of lexemes occurring in the text. Isotopic analysis then consists in the identification of groups of lexemes sharing at least one common feature. Since it concerns relations between text elements it necessarily considers the organization of lexemes into semantic groups within the text (and the relation of members of such groups to each other) rather than the semantic specification of individual lexemes outside the given context in which they occur. For this reason the features (or semes) recurring within a text are considered to be context-related; i.e. only by virtue of its co-occurrence with other lexemes in a particular context does a given lexeme acquire an unambiguous interpretation. As Thiel/Thome (1987: 58) and Kallmeyer et al. (1980: 150) make clear, this is a question of the syntagmatic relation between lexemes co-occurring in a text, rather than of the paradigmatic product of the large number of 
possible textual meanings of any given lexeme considered in isolation. ( $C f$. the distinction between virtual and actual meaning.)

An examination of a corpus of ad hoc forms such as that undertaken in Mealing (1988) reveals that these compounds are generally anaphoric in nature, although in some instances a cataphoric relation to a following part of the text co-occurs. Three types of anaphora can be distinguished, according to the relation of the components of which the compounds consist to the preceding context:

1) explicit anaphora, by which is meant the lexical recurrence of a previously occurring form;

2) implicit anaphora, i.e. the recurrence of one or more semantic features in a component as are contained in the preceding text (this relation concerns not the lexical forms themselves, but semantic relations between them);

3) partial anaphora, which is instanced in those forms with one anaphoric and one cataphoric component. The anaphor in these cases also can be either explicit or implicit.

With this rough outline in mind, consider now some text excerpts which contain ad hoc compounds.

Example 1 Günter Grass, Kopfgeburten

Gedankenknäuel

p. 165: Denn jener erdfarben abgestufte Wintershawl, den Ute während unserer Eisenbahnreise von Shanghai nach Kwelin zu stricken begonnen. . hatte, wurde...zu Weihnachten fertig, weil Ute am Faden geblieben war, während meine Gedankenknäuel...jetzt noch... wirr zuhauf liegen.

isotopy 1: thought

lexemes: Gedanke, Faden / am Faden geblieben

isotopy 2: knitting

lexemes: Wintershawl, stricken, Faden / am Faden geblieben, Knäuel

Knäuel, which actually means balls of wool, coheres isotopically with Wintershawl, stricken (knit) and Faden (thread)/am Faden geblieben ("remained on the thread"). Note, however, that Faden also is used metaphorically in the lexicalized phrase der rote Faden (the red thread) to refer to the logical development of thought in texts, and also in the lexicalized compound Gedankenfaden (thread of thought). By paradigmatic association with these two lexicalized forms, therefore, this single compound coheres not only with the isotopy knitting, but also with that of thought, which is formed together with Gedanke. In this way, Faden bridges the gap between the two isotopies, and allows both components of the compound to cohere anaphorically with the preceding text, thereby allowing for interpretation of the metaphor. This compound is constructed by means of implicit anaphora of both components.

\section{English: Headbirths}

p. 131: For the muffler in graduated earth colors that Ute had started knitting during our train trip from Shanghai to Kwelin (...) was finished at Christmas, because Ute had stuck to the thread, while my thought threads (...) are still in a hopeless tangle.

isotopy 1: thought

isotopy 2 : muffler, thread(s), knitting

By contrast, in the English target text, the anaphora of the first component has been lost. The second component, threads, takes up the isotopy expressed by the forms muffler, knit and thread, but the implicit allusion to thought of the German Faden, which 
specifies the relation between the two components of the compound, is not achieved in the translation. Consequently, the semantic connection of thought to thread, i.e. the connection between the components, is greatly weakened in the target text.

The translator has in fact tried to duplicate the connection by rendering the phrase am Faden geblieben as stuck to the thread (which however is unidiomatic in English), and by translating Knäuel as thread rather than ball. Nevertheless, the lexical recurrence of the second component does not assure meaningful relation, while the first component effectively is left dangling, with no clear co-referent. In the source text the ad hoc form can be meaningfully interpreted precisely because Faden is assigned to both isotopies, whereas in this English translation thread belongs only to the second.

French: Les enfants par la tête

p. 140: Car ce cache-nez d'hiver à nuances terreuses dégradées, que Ute avait commencé à tricoter dans le train de Shanghai à Kwelin... fut terminé à Noël parce que Ute avait gardé le fil tandis que mon peloton de pensées... maintenant encore... forme un tas confus.

isotopy 1: pensées, garder le fil

isotopy 2: cache-nez d'hiver, tricoter, fil, peloton

The other translation of this text is more successful. French renders the ad hoc form as a syntagm, which in itself clarifies to some extent the syntagmatic relation of the components. This structural information, however, does not establish the basis for the metaphor, which is entirely text-dependent.

Peloton coheres anaphorically with the other lexemes belonging to the knitting isotopy (cache-nez $d$ 'hiver, tricoter and fil), and comes closer in meaning to the German Knäuel than does threads. It is semantically connected with pensées by means of the expression garder le fil, which by implicit association with lexicalized forms such as le fil conducteur, le droit fil, makes possible the same connection between the isotopies as in the source text. Retention of the same isotopic relations as in the original has therefore resulted in relative equivalence in translation.

Example 2 Thomas Mann, Der Tod in Venedig Romanteppich

p. 11: Der Autor der klaren und mächtigen Prosa-Epopöe vom Leben Friedrichs von Preußen; der geduldige Künstler, der in langem Flei $\beta$ den figurenreichen, so vielerlei Menschenschicksal im Schatten einer Idee versammelnden Romanteppich, Maja mit Namen wob...

isotopy 1: literature

llexemes: Autor, Roman, Künstler, figurenreich, Prosa-Epopöe

isotopy 2 : carpets / weaving

lexemes: wob, Teppich, figurenreich

isotopy 3: patience

lexemes: geduldig, in langem Flei $\beta$

This form consists of one anaphoric and one cataphoric element, each of which is dependent on a separate isotopy. Roman-coheres anaphorically with Autor, figurenreich (rich in (rhetorical) figures), Künstler (artist) and Prosa-Epopöe (prose epic); these forms together build an isotopy relating to literature. -Teppich on the other hand coheres with wob (wove), and also figurenreich, which in this second interpretation means rich in design. This lexeme forms part of both isotopies because of the polysemicity of Figur. 
There is also a third isotopy, namely that expressed by the lexemes geduldig (patient) and in langem Fleiß (taking great pains). It is by means of this latter isotopy that the processes of writing novels and of weaving tapestries are connected, thereby allowing for metaphorical interpretation of the compound.

English: Death in Venice

p. 8: (...) and this particular artist: author of the lucid and vigorous prose epic on the life of Frederick the Great; careful, tireless weaver of the richly patterned tapestry entitled Maia, a novel that gathers up the threads of many human destinies in the warp of a single idea; [...]

isotopy 1: artist, author, prose epic, novel

isotopy 2: weaver, richly patterned, tapestry, threads, warp

isotopy 3: tireless, careful

The English translator has altered the situation by somewhat underrepresenting the first isotopy and considerably expanding the second. Figurenreich has been assigned only to the second isotopy (as richly patterned). Additionally, threads and warp have been added to this second isotopy, whereas they do not occur at all in the original. Furthermore, weave in the source text occurs as a verb, while in the target text it has been altered to a noun ${ }^{4}$, specifically a nomen agentis which, however, usually denotes habitual activity.

This two-fold shift in perspective places a much greater emphasis on the idea of the writer as artisan than as artist, which represents a significant departure in meaning from the original. Additionally, the components of the German compound have been split up. Although novel still functions anaphorically (as in the original), tapestry is no longer cataphoric, as a result of this reorganization. Because of the division of the compound, the metaphor is expressed explicitly, whereas in the source text, it is formally implicit. This however does not result from structural rules of English. The translator could for example have rendered Romanteppich as fictional tapestry, which, while it does not represent the same degree of abstraction as the German, would at least preserve the syntagmatic relation of the original.

French: La mort à Venise

p. 57: L'auteur du limpide et puissant récit de la vie épique de Frédéric de Prusse, le patient artiste qui dans son roman Maia, comme en un tapisserie où mille personnages s'assemblent à l'ombre d'une idée, s'était longuement appliqué à entrelacer des destinées diverses...

isotopy 1: auteur, récit, roman, artiste

isotopy 2: tapisserie, entrelacer

isotopy 3: $\mathrm{s}$ 'appliquer longuement, patient

In the French text also, the metaphor is made explicit. Here, however, this is a result of a tendency in the linguistic norm, in accordance with which paraphrastic or descriptive forms are preferred. There is therefore a linguistic motivation for the translator's decision. The isotopies are in this version also unsatisfactorily represented, however, since figurenreich is missing altogether: it is rendered in neither isotopy. Nevertheless, the isotopies are otherwise accurately reproduced. This translation, like the English, does not express the ad hoc form as a single syntagmatic unit. Yet because of the rather closer rendering of the semantic relations expressed in the isotopies, and the patterns of recurrence, this text more closely resembles the German than does the English version. 
Example 3 Peter Handke, Die linkshändige Frau

Machtschuhe, Einschüchterungsgesicht, Macht-Starren

p. 62: Bruno sagte zu dem Kind: "Stefan, ich werde dir jetzt zeigen, wie ich die Leute einschüchtere, die zu mir ins Büro kommen... Es ist auch wichtig, bestimmte Schuhe zu tragen, solche mit Kreppsohlen, wie die hier zum Beispiel: das sind Machtschuhe... Man mu $\beta$ es schaffen, eine Aura von Geheimnis auszustrahlen und das wichtigste dabei ist das Einschüchterungsgesicht." Er setzte sich vor die Frau hin und fing zu starren an.

p. 63: ... "Und das ist nun also mein Macht-Starren, mit dem ich hoffe, bald Vorstandsmitglied zu sein."

isotopy 1: power

lexemes: Macht, Einschüchterung-, einschüchtern, Aura, schaffen

isotopy 2: appearance

lexemes: eine Aura ausstrahlen, -Gesicht, starren/(Macht)-Starren, Schuhe/-Schuhe, Kreppsohlen

Two isotopies run through this microtext: that of power and that of appearance. They are related in that Bruno seeks to exercise power over others by impressing them with his appearance. All three of the ad hoc compounds are connected to both isotopies. The first component of each coheres anaphorically with the power isotopy, Einschüchterung- explicitly, Macht- implicitly. In the case of Machtschuhe and Macht-Starren, the second components also reiterate previously occurring lexemes. These latter components form part of the isotopy relating to appearance. In Einschüchterungsgesicht, -Gesicht cataphorically relates the compound to the following description of Bruno's stare. The second component of this form also belongs to the appearance isotopy.

\section{English: The Left-handed Woman}

p. 43-44: Bruno said to the child, "Stefan, I'm going to show you how I intimidate people who come to my office [...] It's also important to wear a certain kind of shoes, with crepe soles, like these that I'm wearing; they're power shoes. One has to emanate an aura of mystery. But the main thing is the intimidating face." He sat down facing the woman and began to stare [...] "This is my power stare, with the help of which I hope to become a member of the board soon."

isotopy 1: intimidate, power, intimidating

isotopy 2: emanate an aura, shoes, crepe soles, face, stare, (power) stare

In this target text the isotopic relations have been somewhat altered from those observed in the source text. This is in part due to the different lexicalized definitions of the etymologically related Aura/aura. In German, this lexeme refers not only to emanations but also to power ${ }^{5}$, whereas in English it denotes only emanations ${ }^{6}$. In the source text therefore Aura belongs to both isotopies, whereas in the target text it forms part only of the second. Furthermore, schaffen (manage) presupposes a strength from which the possibility of doing something arises, and thus belongs to the power isotopy. This has been completely lost in the translation (One must...). As a result the first isotopy is rather weakly reproduced here. The second isotopy by contrast is rendered more faithfully; there is in this respect no semantic discrepancy between source and target text. The cataphoric and anaphoric relations of the source text are preserved here as well.

Two of the German compounds also are rendered as compounds in translation, so that there is a high degree not only of textual but also of morphological similarity between the two versions. Einschüchterungsgesicht, however, has been translated as a 
paraphrastic syntagm, which is markedly less abstract than the compound. This can in fact be attributed to factors relating to the norm of English ( $c f$. below).

French: La femme gauchère

p. 54-56: Bruno dit à l'enfant: «Stéphane, je vais te montrer maintenant comment je m'y prends pour intimider les gens qui viennent ici au bureau [...] Il est important, aussi, de porter un certain type de chaussures avec des semelles de crêpe comme celles-ci par exemple: ce sont des chaussures d'autorité [...] Il faut arriver dégager une aura de puissance; et le plus important, c'est le visage d'intimidation» [...] Il s'assit devant la femme et se mit à regarder fixement $[. .$.$] «Et ça, c'est mon regard maître grâce auquel j'espère être bientôt membre du$ conseil d'administration.»

isotopy 1: intimider, autorité, puissance, intimidation, maître, arriver à

isotopy 2: dégager une aura de (puissance), chaussures, semelles de crêpe, visage, regard

In this version the first isotopy has been expanded, while the second is almost as in the original. Autorité and maitre are the additions, whereby autorité is semantically weaker than the other lexemes in this first isotopy; the text therefore gains nothing from its addition. Puissance has been connected to an element of the second isotopy (dégager une aura de puissance) in such a way as to associate aura with both isotopies ${ }^{7}$, although the idea of mystery is lost as a consequence. The first compound has been translated here as chaussures d'autorité, which is a syntagm. As was briefly indicated in relation to the English translation, syntagms generally do not convey the same degree of abstraction as do compounds; consequently, the interpretation which the original Machtschuhe imposes, i.e. that Macht-is somehow intrinsic in the -Schuhe, is lost here. The same is true of the second compound: visage d'intimidation represents a decidedly less abstract concept than does Einschüchterungsgesicht. The third form, Macht-Starren, however, is more successfully translated as regard maitre. Since this also is a compound structure, the translator has in this instance succeeded in approximating the semantic relation between the components of the German form. The semantic feature of power is also preserved in maitre, which denotes someone in a position to exert authority over others.

The first two compounds could have been more successfully translated by other means, however. Chaussures-puissance, for instance, would have been better than chaussures d'autorité, as the compound structure would have more closely rendered the relation of the components of Machtschuhe. In the second instance, visage intimidateur would have been preferable to the translation actually made, since intimidateur implies an inherent property of the noun it modifies. These alternate translations, therefore, would have more closely rendered the meaning relations between the components of the ad hoc compounds ${ }^{8}$.

It has been demonstrated in this paper that acceptable translation of ad hoc compounds depends on the interaction of both the structural potential of a language, as determined by the system, and the operative semantic-pragmatic factors in the text. This is in accordance with the accepted precepts of translation theory. There is also a third criterion, however, which must be taken into account, namely the linguistic norm. The norm can exert a direct influence on the structures preferred in a translation ${ }^{9}$ on the basis of paradigmatic relation to lexicalized forms.

For instance, Einschüchterungsgesicht is not translated into English as intimidation face, since there is a tendency in the norm of the language to prefer a syntagm constructed of a deverbal adjective plus a noun over a compound consisting of two noun stems, where the first stem is a deverbal abstract noun. Thus for example for the German Verbindungstür, Verbindungsstück, Verbindungsstraße (where Verbindung- is a deverbal 
abstract noun meaning 'connection'), the corresponding English forms are lexicalized syntagms: connecting door, connecting piece, connecting road. Similarly for the following pairs with Untersuchung- (examination) as first component: Untersuchungsausschuß/-komitee - fact-finding committee, Untersuchungsrichter — examining magistrate, etc. By contrast, English commonly constructs compounds with non-deverbal nouns as first component, as in the following examples with power: power-hunger, power distribution, power breakfast, etc.

There is then a compound formation model of English which allows $\mathrm{N}+\mathrm{N}$ structures; whether or not this possibility is in fact utilized in a particular instance can depend in part on the paradigmatic relations of a given component to lexicalized forms found in the norm. It is therefore by analogy to lexicalized compounds with power that Machtschuhe can be translated as power shoes, rather than shoes of power ${ }^{10}$, for instance, while lexicalized forms such as connecting road, examining magistrate indicate a tendency to avoid compounds with a deverbal abstract noun in first position ${ }^{11}$. This therefore makes intimidating face a more acceptable translation of Einschüchterungsgesicht than intimidation face, in spite of the loss of abstraction it effects.

That the interaction of the three levels of Coseriu's hierarchy is of a highly complex nature is evidenced perhaps most clearly in the French translation of the Handke text excerpt. It will be recalled that the first two ad hoc forms were translated as syntagms, although French in principle also permits $\mathrm{N}+\mathrm{N}$ compounds ( $c f$. for instance regard mattre). It is because of the influence of the linguistic norm of French, which generally prefers syntagmatic structures where German permits compounds, that these forms were translated in a paraphrastic manner.

Nevertheless, as discussed above, this resulted in a departure from the semantic relations expressed in the source language text. Because of the semantic-pragmatic criteria of this text, the compound Machtschuhe is more closely translated by chaussurespuissance than by chaussures d'autorite, or even chaussures de puissance. For Einschüchterungsgesicht on the other hand it was not necessary to deviate from the norm in order to arrive at an equivalent meaning. Although a change was proposed, this was not a change from a preferred structure of the norm to a less common one.

The process of translation always involves establishing paradigms of possible variants, from which the optimal form is chosen. What constitutes an optimal choice is always determined by the context of use, by which is understood all of those semantic and pragmatic factors which influence text constitution. Thus the semantics and pragmatics of the source language text must be accorded a high priority in translation. The rneaning relations expressed in the text must be reproduced as closely as possible in the target language text if equivalence is to be achieved. To do this, the translator must deterrnine first the Sinn of the text under consideration and then the means by which this is constructed.

Determination of relations of isotopy and recurrence is a useful method of accomplishing this task, as it provides an objective basis for text analysis. In this way, that translation which most closely approximates the meaning ( $\operatorname{sinn}$ ) of the source text can be chosen from the paradigm of possible solutions. Levy (1967: 1171, 1173) argues that the members of a translation paradigm are not completely equivalent elements, but rather that the choice among them is context-bound. Consideration of recurrence and isotopy allows for a motivated choice in this regard. It also in some measure provides a criterion not only for adequate translation as process, but also for the evaluation of a given translation, i.e. translation as product.

Moreover, insofar as this identifies specific processes of text constitution, which then are relevant for both source and target text, it also makes possible a much more 
precise and accurate description of translation procedures than has previously been the case. The stylistique comparée, for instance, identifies procedures such as modulation, transposition, etc. Yet these terms are really labels for structural differences observable between any source and target language pair, which however, do not identify a textual motivation for a translation. Given that text is now a sine qua non for translation, it would seem important also to incorporate the text linguistic findings elaborated here into the theory of translation.

\section{NOTES}

1. There is a basic distinction made between virtual and actual meaning ( $c f$. for instance Bally (1944: 77)), whereby the virtual represents all of the potential meanings of a linguistic sign, while the actual meaning is determined by the sign's use in some particular context.

2. Although it is not common in English, I employ the distinction made in German between Texttyp (text type) and Textsorte (text sort). Texttyp refers to the classification of texts according to the predominant communicative function expressed by them ( $c f$. e.g. Reiss' (1969) three text type categories, namely informative, expressive and operative). Textsorten on the other hand are specific text models which realize one or another text type. (Cf. Königs (1981: 327-328).) For example, novels, novellas, short stories, etc. are separate text sorts, all of which instantiate the same text type, namely the expressive.

3. Coherence concerns the semantic and pragmatic connectivity of the text, cohesion the linguistic expression of this. Cf. e.g. Dressler (1987: 21-22).

4. At first sight this might appear to be an instance of transposition (to use the term of the stylistique comparée). Since Vinay / Darbelnet (1958: 50) in fact define transposition as a process which consists in replacing one part of speech by another without changing the meaning (emphasis mine - C.M.), the term cannot be applied here. As Clas (1971) observed, the translator always works with semantic units, whereas most of the procedures identified in the stylistique comparée operate on formal units. For this reason, the stylistique comparée is not applied in this paper.

5. Cf. e.g. Wahrig (1974)

6. Cf. e,g, the Oxford English Dictionary (1989).

7. The French aura is otherwise understood as is the English lexeme. $C f$. Robert (1985)

8. I would like to thank Hélène Morin for suggesting these more accurate translations.

9. It of course also plays a role at other levels. Text sorts, for instance, result in large measure from specific norms of text type realization.

10. The adjective powerful is excluded here on semantic grounds, as it would imply either that the shoes were strong, or that they were motorized.

11. It should be noted that this is a tendency observed in English, and not a rule.

\section{REFERENCES}

\section{Primary Literature}

GRASS, Günter (1980) : Kopfgeburten oder Die Deutschen sterben aus, Darmstadt, Luchterhand.

GRASS, Günter (1982): Headbirths or the Germans are Dying out, New York, Harcourt Brace Jovanovich, translated by Ralph Manheim.

GRASS, Günter (1983) : Les enfants par la tête ou les Allemands se meurent, Paris, Éditions du Seuil, translated by Jean Amsler.

HANDKE, Peter (1981) : Die linkshändige Frau, Frankfurt/Main, Suhrkamp.

HANDKE, Peter (1980): The Left-handed Woman, London, Eyre Methuen, translated by Ralph Manheim.

HANDKE, Peter (1978): La femme gauchère, Paris, Gallimard, translated by Georges-Arthur Goldschmidt.

MANN, Thomas (1984) : Der Tod Venedig und andere Erzählungen, Frankfurt/Main, Fischer.

MANN, Thomas (1963) : Death in Venice and Seven Other Stories, New York, Vintage Books / Random House, translated by H.T. Lowe-Porter.

MANN, Thomas (1962) : La mort à Venise, Paris, Les Presses du Compagnonnage, translated by Félix Bertaux.

\section{Secondary Literature}

BALLY; Charles (1944) : Linguistique générale et linguistique française, Bern, A. Francke.

CLAS, André (1971) : "L'opération traduisante", K.-R. Bausch / H.-M. Gauger, eds., Interlinguistica, Tübingen, Niemeyer, pp. 607-609.

COSERIU, Eugenio (1978): "Falsche und Richtige Fragestellungen in der Übersetzungstheorie", reprinted in: W. Wilss, ed. (1981). Übersetzungswissenschaft, Darmstadt: Wissenschaftliche Buchgesellschaft, pp. $27-47$. 
COSERIU, Eugenio (1975): "System, Norm und Rede", E. Coseriu, Sprachtheorie und Allgemeine Sprachwissenschaft, Munich, Fink, pp. 11-101.

DRESSLER, Wolfgang (1987): "Die Bedeutung der Textlinguistik für die Übersetzung und Umkodienung", Atti del Convegno "Tradurre", Bozen/Bolzano, Educazione Bilingue, pp. 21-34.

DRESSLER, Wolfgang (1981d): "Zum Verhältnis zwischen Wortbildung und Textlinguistik", J. Petöfi, ed., Text vs Sentence Continued, Hamburg, Buske, pp. 96-106.

KALLMEYER, Wemer et al. (1980): Lektürekolleg zur Textlinguistik, Königstein / Ts., Athenäum, 1.

KOMISSAROV, Vilen (1987): "The Semantic and the Cognitive in the Text: A Problem in Equivalence", Meta 32, pp. 416-419.

KÖNIGS, Frank (1981): "Übersetzungswissenschaftliche Terminologie”, K.-R. Bausch/F. R. Weller, eds., Übersetzen und Fremdsprachenunterricht, Frankfurt am Main / Berlin / Munich, Diesterweg, pp. 315-348.

LEVY, Jiri (1967): "Translation as a Decision Process", To Honor Roman Jakobson, II, The Hague, Mouton, pp. 1171-1182.

MARCHAND, Hans (1967): "On the Description of Compounds", Word 23, pp. 379-387.

MEALING, Catherine (1988): German Noun Compounds and their Role in Text Cohesion, unpublished M.A. Thesis, Department of German, McGill University, Montréal.

NEUBERT, Albrecht (1981) : “Übersetzungswissenschaftlicher Sprachvergleich”, Fremdsprachen 25, pp. 24-29. The Oxford English Dictionary (1989), London, Oxford UP.

POLENZ, Peter von (1985) : Deutsche Satzsemantik, Berlin/New York, de Gruyter

REISS, Katharina (1969): "Textbestimmung und Übersetzungsmethode", reprinted in W. Wilss, ed. (1981), Übersetzungswissenschaft, Darmstadt, Wissenschaftliche Buchgesellschaft, pp. 76-91.

Le Robert: Dictionnaire de la langue française (1985), Paris, Robert.

SCHRÖDER, Marianne (1985) : "Überlegungen zur textorientierten Wortbildungsforschung", W. Fleischer, ed., Textbezogene Nominationsforschung, Oberlungwitz, VEB, pp. 69-94.

SCHRÖDER, Marianne (1978): "Über textverflechtende Wortbildungselemente", Deutsch als Fremdsprache 15 , pp. 85-92.

THHEL, Gisela/Gisela THOME (1987): Resolutionen: Ein empirisch entwickelter Beitrag zur Textanalyse, Tübingen, Gunter Narr.

VINAY, J.-P. / J. DARBELNET (1958) : Stylistique Comparée du Français et de l'Anglais, Paris, Didier.

WAHRIG, Gerhard (1974) : Deutsches Wörterbuch, Berlin / Munich / Vienna, Bertelsmann.

WILSS, Wolfram (1981): "Handlungstheoretische Aspekte des Übersetzungsprozesses", W. Pöckl, ed., Europäische Mehrsprachigkeit, Tübingen, Niemeyer, pp. 455-468. 